\title{
MORFOLOGI DAN KEAMANAN PATI SAGU RUMBIA (METROXYLON SAGU ROTTB) UNTUK GELATIN DALAM APLIKASINYA SEBAGAI CANGKANG KAPSUL
}

\section{MORPHOLOGICAL AND SECURITY OF RUMBIA SAGO STARCH (METROXYLON SAGU ROTTB) TO GELATIN WITH APPLICATION AS CAPSULE SHELL}

\author{
Hamlan Ihsan, Desi Mustika Amaliyah, Dwi Harsono, \\ Sri Hidayati, Fitri Yuliati, dan Miyono \\ Balai Riset Dan Standardisasi Industri Banjarbaru \\ Jalan Panglima Batur Barat No.2, (0511)4774861, 4772461/Fax. (0511)4772115 \\ E-mail: hamlan.ihsan@ymail.com
}

Diterima : 29 Juni 2020 Direvisi : 8 Juli 2020 Direvisi : 11 November 2020

\begin{abstract}
ABSTRAK
Sagu rumbia (Metroxylon sagu Rottb) adalah tanaman liar yang berkembang biak dengan cara bertunas. Bagian paling penting dari sagu adalah batang (empulur) sebagai tempat penyimpanan pati. Kalimantan merupakan salah satu kawasan penghasil sagu terbesar ke 6 di Indonesia dan sampai saat ini pemanfaatannya kurang optimal. Penelitian ini bertujuan untuk melakukan analisis morfologi dan tingkat keamanan pati sagu sebagai pengganti gelatin hewani dalam aplikasinya untuk pembuatan cangkang kapsul. Metode yang digunakan pada penelitian ini cross-linking dengan propilen oksida. Proses ini dilakukan pada pH 10,5 dengan suhu $25^{\circ} \mathrm{C}$ selama 30 menit untuk mengubah sifat fisik dan morfologi dari pati sagu agar mendekati dengan sifat gelatin komersial. Hasil penelitian ini merupakan analisis sifat morfologi berdasarkan kesamaan gugus fungsi serta tekstur tofografi dari bahan baku. Pengujian aflatoksin dilakukan sebagai pertimbangan keamanan sediaan. Hasil analisis morfologi FTIR dan SEM untuk sagu modifikasi dengan tambahan filler karagenan identik dengan gelatin komersial, yaitu pada bilangan gelombang $3283 \mathrm{~cm}^{-1}$. Sedangkan pada pengujian SEM rongga yang terbentuk pada pembesaran 5000 kali dibagian permukaan memiliki kesamaan dengan gelatin. Kandungan jenis aflatoksin $B_{1}$ dan $B_{2}$ masing-masing $<1,42$ dan $<6,72 \mathrm{ppb}$, sedangkan jenis $G_{1}$ dan $G_{2}$ masing-masing adalah $<5,09$ dan $<0,66 \mathrm{ppb}$. Hasil ini jauh di bawah standar yang dipersyaratkan yaitu $<20 \mathrm{ppb}$ untuk pangan dan $\leq 5 \mathrm{ppb}$ untuk aflatoksin $\mathrm{B}_{1}$.
\end{abstract}

Kata kunci: aflatoksin, filler, FTIR, karagenan, SEM

\begin{abstract}
The sago palm (Metroxylon sago Rottb) is a wild plant that reproduces by sprouting. The most important part of sago is the stem (pith) where starch is stored. Kalimantan is one area of the sago producers the $6^{\text {th }}$ largest in Indonesia but the its utilization is not fully optimized. This research aim is to morphological analysis and safety level of sago starch as a substitute for animal gelatin in application for making capsule shells. The method used in this research is cross-linking with propylene oxide. The process does $\mathrm{pH}$ 10,5 with temperature $25{ }^{\circ} \mathrm{C}$ for 30 minutes to change physical and morphological characteristics of sago starch to approach commercial gelatinous properties. The research result is an analysis of morphological properties based on the similarity of functional groups and the topographic texture of the raw material. Aflatoxin was tested as a safety consideration for the dosage form. The results of FTIR and SEM morphological analysis for modified sago with the addition of carrageenan filler is identical to commercial gelatin, at wave number $3283 \mathrm{~cm}-1$. In SEM testing, the cavities formed at 5000 magnification times of the surface have similarities to gelatin. The content of the aflatoxin types $B_{1}$ and $B_{2}$ respectively $<1.42$ and $<6.72 p p b$, while the types of $G_{1}$ and $G_{2}$ are
\end{abstract}


$<5.09$ and $<0.66 \mathrm{ppb}$. These results are far below the required standards of $<20 \mathrm{ppb}$ for food and $\leq 5$ ppb for aflatoxin $B_{1}$.

Keywords: aflatoxin, filler, FTIR, carrageenan, SEM

\section{PENDAHULUAN}

D umbia (Metroxylon sagu Rottb) atau biasa dikenal dengan nama pohon sagu merupakan salah satu jenis tanaman perkebunan. Penyebaran tanaman ini dimulai dari wilayah barat Indonesia yaitu Kepulauan Riau, wilayah tengah yaitu Kalimantan Selatan sampai di Papua pada wilayah Timur Indonesia. Areal tanaman sagu di Indonesia mencapai 1,128 juta ha atau 51,3\% dari 2,201 juta ha areal sagu dunia (Wahida dan Limbongan, 2015). Bagian yang paling penting dari sagu adalah bagian tengah batang (empulur) yaitu tempat akumulasi pati dengan kandungan amilopektin sebesar $73 \%$ dan 27\% amilosa (Bantacut, 2011).

Penelitian yang dilakukan oleh Ihsan $(2018,2019)$ untuk melihat keamanan bahan baku sagu terhadap cemaran logam berat dan cemaran yang berasal dari mikroba, dimana memberikan hasil analisa negatif untuk cemaran logam berat yang merupakan syarat baku dibidang pangan dan farmasi. Sedangkan untuk cemaran mikroba yang dipersayatkan Departemen Kesehatan RI pada jenis E. coli, Salmonella Sp, dan Staphylococcus aureus memberikan hasil analisa dibawah standar.

Pengembangan bioplastik dengan bahan baku seperti jagung dan ubi telah banyak dilakukan, akan tetapi masih memiliki kekurangan yaitu sifat mekaniknya yang rendah. Menurut (Widyaningsih et al., 2012), sifat mekanik dari pati sagu yang memilki kandungan amilopektin dan amilosa dapat ditingkatkan dengan memodifikasi serta menambahkan filler dan plastisizer sehingga mampu mengurangi kerapuhan serta meningkatkan fleksibilitas dan ketahanan film dalam aplikasinya sebagai cangkang kapsul.

Pemanfaatan pati sagu sebagai bahan substitusi gelatin pada pembuatan cangkang kapsul dapat mengurangi ketergantungan ataupun impor gelatin komersial khususnya di Indonesia. Gelatin banyak dimanfaatkan dalam industri farmasi (pembuatan kapsul). Gelatin ini diimpor dari negara-negara seperti China, Jepang, Jerman, Perancis, Australia, India maupun Selandia Baru. Dalam penggunaannya, gelatin yang beredar di dalam negeri hampir $90 \%$ adalah gelatin impor yang diketahui diproduksi dari bahan baku kulit dan tulang hewan (Said et al., 2011). Penggunaan gelatin yang beragam tidak diimbangi dengan tumbuhnya produksi gelatin dalam negeri sehingga kebutuhan dalam negeri terhadap gelatin dipenuhi dengan cara impor. Data impor gelatin berdasarkan Biro Pusat Statistik (2014) menyatakan bahwa indonesia mengalami kenaikan impor dari tahun 2010 - 2014 sebesar 7,22\% yaitu dari 3.150 ton menjadi 3.872 ton.

Gelatin memiliki kegunaan yang sangat luas dibidang farmasi khususnya dalam pembuatan cangkang kapsul. Beberapa negara maju sudah mulai mengembangkan pengganti gelatin yang pada umumnya adalah berasal dari hewani menjadi gelatin yang bersumber dari nabati. Hal ini juga dikembangkan di Indonesia pada penelitian yang dilakukan oleh Kristianto (2014), cangkang kapsul untuk drug delivery carrier dari ekstraksi rumput laut jenis Eucheuma spinosom dengan metode crosslink oleh alginat. Dari hasil analisis disolusi kapsul tersebut, diperoleh kapsul dengan potensi yang sebanding dengan kapsul standar buatan pabrik meskipun hasil pengujian swelling yang masih belum optimal. Pada penelitian (Fakharian et al., 2015; Oladzadabbasabadi et al., 2016) dikembangkan film berbasis pati sagu dan karagenan sebagai alternatif pembuatan gelatin farmasi. Hasil analisis nilai viskositas, uap air, dan kadar air yang masih belum sebanding dengan gelatin komersial. Pati sagu termodifikasi propilen oksida pada penelitian ini diharapkan mampu memberikan hasil uji yang sebanding dengan gelatin komersial. 
Dalam industri farmasi, bahan baku yang nantinya akan dipergunakan sebagai substitusi, harus memiliki standar keamanan, khususnya kandungan toksik. Aflatoksin merupakan salah satu cemaran alami yang berbahaya bagi kesehatan manusia karena bersifat karsinogenik

Indonesia terletak di daerah khatulistiwa yang memiliki iklim tropis dengan suhu udara dan kelembapan yang tinggi sehingga komoditas sangat rentan terhadap kontaminasi aflatoksin. Selain itu pengujian aflatoksin juga menjadi standar mutu obat yang dipersyaratkan oleh Badan Pengawas Obat dan Makanan (BPOM).

\section{BAHAN DAN METODE Waktu dan Tempat}

Kegiatan penelitian dilaksanakan di Laboratorium Baristand Industri Banjarbaru, Kalimantan Selatan, dilakukan pada bulan Januari - Oktober 2019.

\section{Bahan dan Alat}

Bahan baku utama yang digunakan adalah pati sagu segar yang telah melalui proses pemurnian yang diperoleh dari Desa Margasari Kabupaten Tapin Kalimantan Selatan. Bahan penolong penelitian lainnya antara lain adalah k-karagenan (Filler), kaolin (Filler), gliserol (Plastisizer), silika gel, larutan standar pH 4 dan 7, cangkang kapsul komersial (gelatin hewani), gelatin (Sigma), propilen oksida yang diperoleh dari Laboratorium Farmasi Universitas Lambung Mangkurat Banjarbaru, serta bahan-bahan kimia pro analitik lainnya yang diperlukan untuk analisis.

Alat yang digunakan dalam penelitian ini meliputi oven Memmert, desikator vacum duran, neraca analitik (MARK M5), pH meter digital (EUTECH), waterbath (Memmert), termometer, stopwach, Laminar Air Flow (ESCO), hygrometer, Peralatan kromatografi latis tipis (KLT), Metode Spektroskopi menggunakan Fourier Transform Infrared (FTIR) Mb3000 dengan metode metode Spektroskopi dan Scanning Electron Microscope (SEM) JSM-6510LA dilakukan di Laboratorium MIPA UGM.

\section{Metode dan Analisis Data}

\section{Proses pembuatan pati sagu dari batang rumbia (Metroxylon sagu Rottb)}

Batang rumbia dipotong menjadi ukuran \pm 1 meter untuk memudahkan dalam pemisahan dari kulitnya. Empulur rumbia kemudian dihancurkan dengan menggunakan mesin pemarut sehingga membentuk crude pati. Crude pati dipindahkan secara manual ke dalam bak penampung untuk dilakukan pengadukan dengan kecepatan tertentu. Pati yang terpisah akan mengendap dan dilanjutkan dengan proses pencucian dan penyaringan menggunakan air bersih mengalir dengan perbandingan ampas $1: 2$ air. Pati yang dihasilkan dicuci kembali untuk menjamin kebersihan bahan baku dalam hal penggunaanya. Pati yang sudah bersih dikeringkan menggunakan oven dengan suhu $60{ }^{\circ} \mathrm{C}$ selama 5 jam. Pati yang telah kering kemudian diayak dengan ayakan 150 mesh. 


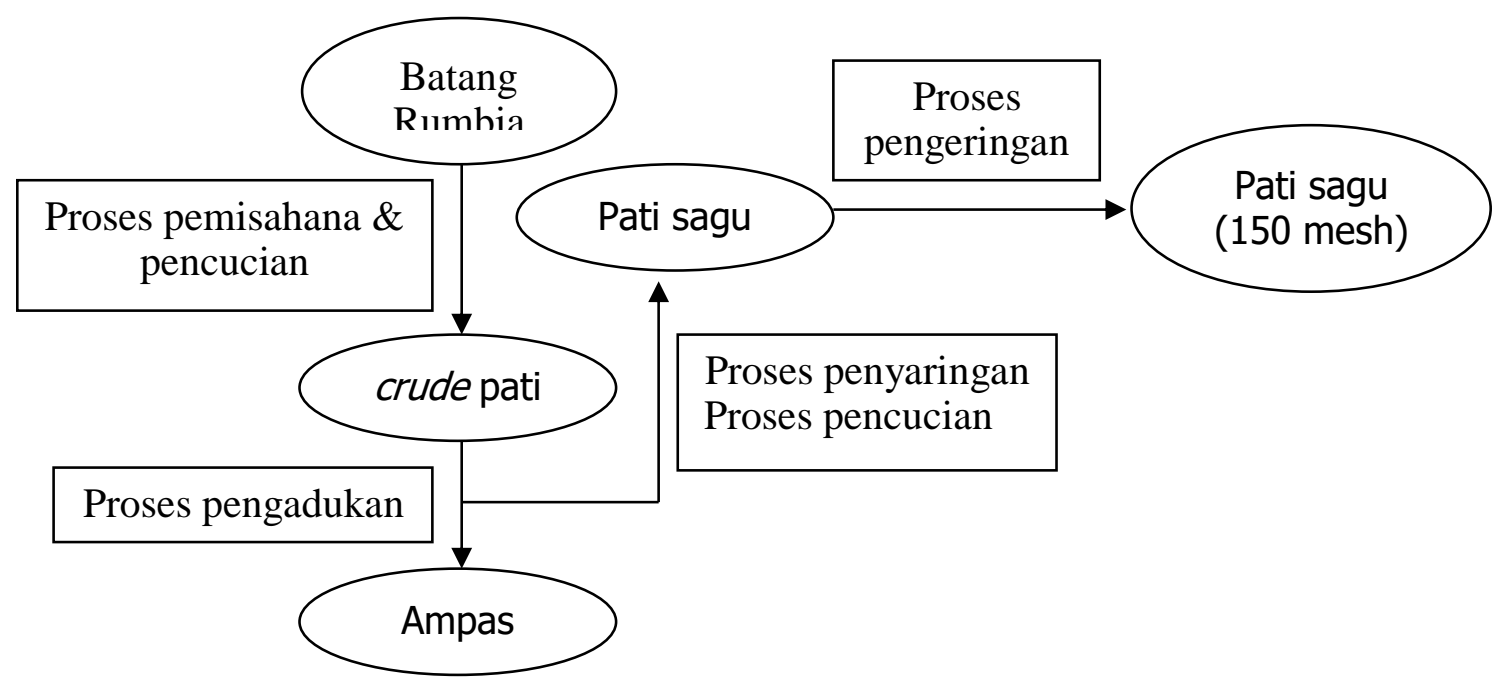

Gambar 1. Diagram alir proses pengambilan pati dari empelur phon rumbia.

\section{Proses modifikasi pati sagu dengan metode cross-linking}

Metode yang digunakan dalam penelitian ini adalah cross-linking yang bertujuan untuk menghasilkan pati yang tahan tekanan mekanis, dan mencegah penurunan viskositas selama proses pemasakan. Pati ikatan silang dibuat dengan menambahkan cross-linking agent yaitu propilen oksida kedalam suspensi pati pada kondisi suhu dan $\mathrm{pH}$ yang sesuai. Dengan sejumlah cross-linking agent pada temperatur tertentu akan menghasilkan viskositas yang stabil (Maulani et al., 2013).

Pati sebanyak $100 \mathrm{~g}$ (berat kering) dilarutkan pada larutan Natrium sulfat $10 \%$, hingga diperoleh suspense 40\% (b/v). Kemudian $\mathrm{pH}$ larutan dinaikkan menjadi 10,5 dengan penambahan $\mathrm{NaOH} 5 \%$. Propilen oksida ditambahkan dengan konsentrasi $10 \%$. Suspensi diaduk selama 30 menit pada suhu kamar $\left(25^{\circ} \mathrm{C}\right)$. Selanjutnya suspensi ditempatkan pada shaker untuk dilakukan pengadukan (rpm 200) selama 24 jam. Endapan dicuci dengan air destilata sebanyak 5 kali dan dilanjutkan dengan proses pengeringan pada suhu $40{ }^{\circ} \mathrm{C}$ sampai kadar air 10-12\% (Maulani et al., 2013).

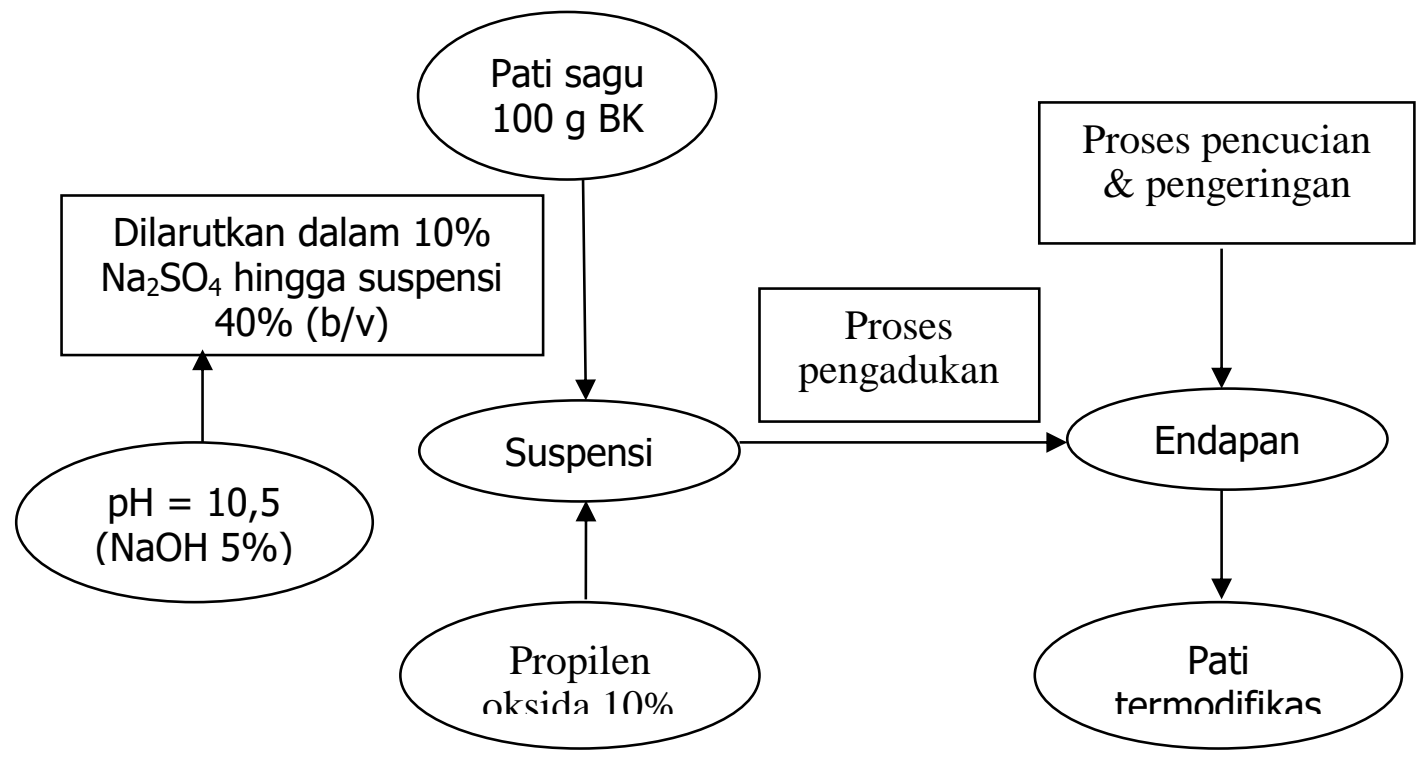

Gambar 2. Diagram alir proses pengambilan pati dari empelur phon rumbia. 


\section{Analisa Data}

Pada analisis data ini akan dilakukan pengujian beberapa variasi dari bahan dasar pati sagu dan pati sagu termodifikasi yang akan ditambahkan bahan filler dan plastisizer untuk memberikan kesamaan sifat morfologi terhadap gelatin komersial. Filler yang digunakan pada penelitian ini antara lain k-karagenan dan kaolin dengan kadar $10 \%$ dan 5\% sedangkan untuk plastisizer digunakan gliserol dengan masing-masing kadar 2\%. Data analisis ini akan dibandingkan dengan gelatin komersial yang merupakan bahan baku pembuatan cangkang kapsul dan juga cangkang kapsul komersial yang digunakan dibidang farmasi.

\section{Pengujian sifat morfologi dan keamanan bahan baku}

Uji FTIR : Pengujian Spektroskopi FTIR (Fourier Transform Infrared) Mb3000 digunakan untuk analisis senyawa kimia dimana spektranya dapat memberikan gambaran dan struktur molekul suatu senyawa. Spektrum IR tersebut dihasilkan dari pentrasmisian cahaya yang melewati sampel, pengukuran intensitas cahaya akan dibandingkan dengan intensitas tanpa sampel sebagai fungsi panjang gelombang. Spektrum inframerah yang diperoleh kemudian diplot sebagai intensitas fungsi energi, panjang gelombang $(\mu \mathrm{m})$ atau bilangan gelombang $\left(\mathrm{cm}^{-1}\right)$ (Crankovic, 1986). Preparasi sampel untuk analisis FTIR pada penelitian ini menggunakan ( \pm 1 gram bk sampel) dan dilakukan di Laboratorium MIPA UGM.

Uji SEM : Pengujian SEM (Scanning Electron Microscopy) JSM-6510LA merupakan mikroskop electron yang digunakan untuk menganalisis permukaan objek (padatan). Preparasi sampel untuk penelitian ini dimulai dengan pengeringan hasil pencetakan edible film sampai dengan kadar air $\pm 5 \%$. Sampel kemudian dipotong dengan ukuran $\pm 1 \mathrm{~cm} \times 1$ $\mathrm{cm}$, sampel diletakkan pada logam yang dilapisi karbon untuk selanjutnya dilapis dengan emas (Au) di dalam Magnetron Sputtering Divice yang dilengkapi dengan pompa vacuum. Sehingga terjadi interaksi antara emas terhadap sampel dan menimbulkan tembakan elektron kearah sampel, reaksi ini akan terekam ke dalam monitor dan kemudian dilakukan pemotretan (Sari et al., 2013).

Uji Aflatoksin : Pengujian aflatoksin menggunakan metode kromatografi lapis tipis (AOAC 2005). Sebanyak $250 \mathrm{~g}$ sampel, $341 \mathrm{~mL}$ akuades, dan $5 \mathrm{~g} \mathrm{NaCl}$ digiling dengan menggunakan blender selama 3 menit. Sebanyak $200 \mathrm{~g}$ sampel yang telah digiling dikemas dengan kantung plastik dan disimpan di dalam freezer sebagai "retain sample". Sampel yang telah berbentuk pasta ditimbang sebanyak $130 \mathrm{~g}$, selanjutnya ditempatkan di dalam labu Erlenmeyer $250 \mathrm{~mL}$ dan ditambahkan $50 \mathrm{~mL}$ larutan $\mathrm{NaCl} 2.2 \%, 150 \mathrm{~mL}$ metanol, dan 100 $\mathrm{mL}$ heksana secara kuantitatif. Campuran ini diaduk menggunakan pengaduk magnet selama 30 menit, kemudian dibiarkan selama 30 menit untuk mendapatkan pemisahan yang baik.

\section{HASIL DAN PEMBAHASAN}

\section{Pengujian Sifat Morfologi Berdasarkan gugus fungsi}

Pengujian FTIR dilakukan untuk melihat perubahan yang terjadi dari hasil modifikasi menggunakan propilen oksida serta membandingkan gugus fungsi yang terbentuk dengan blanko dalam hal ini adalah gelatin komersial serta cangkang kapsul komersial. Gambar 1. merupakan hasil pengujian FTIR dimana puncak-puncak serapan menunjukkan bilangan gelombang yang hampir identik, yaitu pada bilangan gelombang $3000-3300 \mathrm{~cm}^{-1}$ yang mengandung gugus fungsi $\mathrm{CH} ; \mathrm{OH} ; \mathrm{NH}$. 


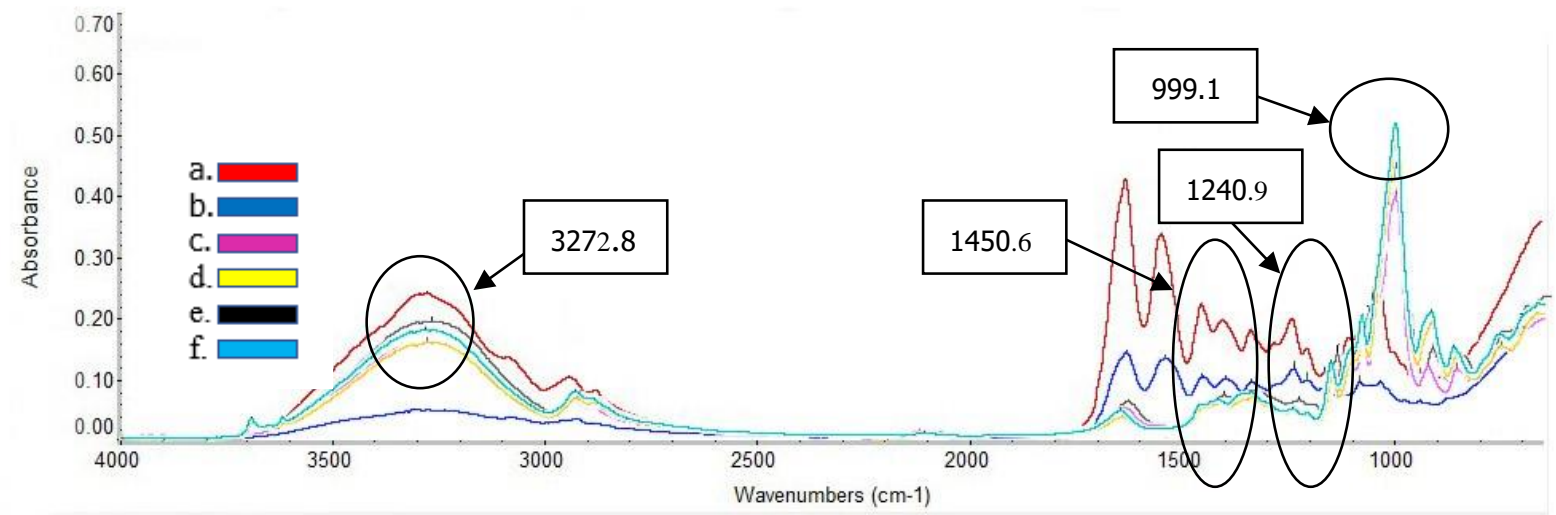

Gambar 3. Hasil pengujian FTIR (a) gelatin komersial, (b) cangkang kapsul komersial, (c) sagu + karagenan, (d) sagu + kaolin, (e) sagu modifikasi + karagenan, (f) sagu modifikasi + kaolin

Berdasarkan penelitian yang dilakukan oleh Roswiem dan Kusuma (2018) hasil gambaran spektrum FTIR gelatin memiliki kesamaan yaitu pada bilangan gelombang $3267,11 \mathrm{~cm}^{-1}$ sebagai ciri dari unsur $\mathrm{CH}$; OH; $\mathrm{NH}$; serta pada bilangan gelombang $1450-1600$ $\mathrm{cm}^{-1}$ untuk ikatan C - C. Sedangkan pada penelitian yang dilakukan Yuliasih et al. (2007) untuk kandungan amilosa yang terdapat pada pati muncul pada bilangan gelombang 3200 $\mathrm{cm}^{-1}$ dan $2900 \mathrm{~cm}^{-1}$ yang merupakan ciri dari puncak $\mathrm{OH}$; dan $\mathrm{CH}$.

Hasil penambahan filler karagenan pada Gamar 1c dan 1e ditandai dengan gugus fungsi ester sulfat terdapat pada bilangan gelombang $1210-1260 \mathrm{~cm}^{-1}$, ikatan glikosidik pada $1010-1080 \mathrm{~cm}^{-1}$, Anhidro-Galaktosa (AG) pada $928-933 \mathrm{~cm}^{-1}$, galaktosa sulfat pada $840-850 \mathrm{~cm}^{-1}$, dan galaktosa 2 sulfat pada $800-805 \mathrm{~cm}^{-1}$ (Setijawati, 2017). Modifikasi dengan propilen oksida terlihat pada Gambar 1e dan if dengan bilangan gelombang yg muncul $2931 \mathrm{~cm}^{-1}$ dan $2928 \mathrm{~cm}^{-1}$. Propilen oksida memiliki rumus kimia $\mathrm{C}_{3} \mathrm{H}_{6} \mathrm{O}$ dan wilayah spektrum antara $3000-2500 \mathrm{~cm}^{-1}$ dengan ikatan yang terjadi adalah $\mathrm{C}-\mathrm{C} ; \mathrm{C}-\mathrm{H} ; \mathrm{C}=\mathrm{O}$ (Fessenden dan Fessenden, 1982).

Berdasarkan Gambar 1b yang merupakan hasil analisis menggunakan FTIR pada cangkang kapsul komersial memberikan gambaran puncak yang terbentuk antara 1627 $927 \mathrm{~cm}^{-1}$. Hal ini sebanding dengan hasil penelitian yang dilakukan Syafiqoh (2014) dimana hasil analisa FTIR terhadap gelatin dari kulit hewan muncul pada bilangan gelombang yang antara $1656-1335 \mathrm{~cm}^{-1}$. Selain itu pada Gambar 1a yang merupakan hasil Analisa FTIR dari gelatin komersial memiliki perbedaan dengan Gambar 1b dalam hal ini cangkang kapsul komersial. Hal ini dikarenakan ikatan N - H stretching yang muncul pada daerah 3290 $3280 \mathrm{~cm}^{-1}$ menunjukkan adanya interaksi ikatan hidrogen pada struktur alpha heliks dalam struktur gelatin tersebut (Hasyim et al., 2010).

\section{Pengujian sifat morfologi berdasarkan topografi tekstur permukaan}

Pada pengujian dengan Scanning Electron Microscope (SEM) yang dilakukan pada pembesaran 1000 dan 5000 kali seperti Gambar 2. Beberapa diantaranya menunjukkan kesamaan antara sampel uji dengan blanko dalam hal ini adalah gelatin komersial (2a) dan cangkang kapsul komersial (2b). Pengamatan gelatin komersial dengan SEM yang dilakukan oleh Ratnasari et al. (2013) menunjukkan struktur gelatin ditandai dengan sponge atau batu karang. Gambar 2a pada bagian penampang terlihat adanya tekstur sepeerti batu karang hal ini juga terlihat Gambar 2e dan $2 f$ pada bagian permukaan untuk sagu modifikasi dengan filler karagenan pada pembesaran 5000 kali. 
Berdasarkan penelitian Rakhman dan Darni (2017) pembuatan bioplastik menggunakan filler $\mathrm{CaCO}_{3}$ dan gliserol memiliki permukaan yang tidak merata dan banyak ruang kosong menandakan pada pembuatan bioplastik yang belum homogen atau kurangnya filler pengisi dan juga terlihat seperti benang dimana menunjukan gliserol yang kurang tercampur rata sehingga belum berpengaruh maksimal pada hasil elastisitasnya. Pada Gambar $2 f$ yaitu variasi sagu termodifikasi dengan filler kaolin memberikan gambaran penampang dan permukaan yang tidak terlalu bergelombang serta ruang yang lebih padat.

$2($ a)

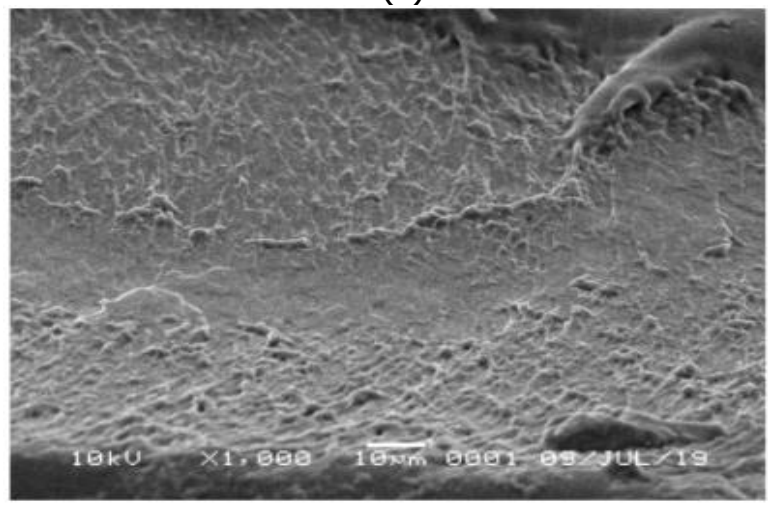

SEM 1000x Penampang

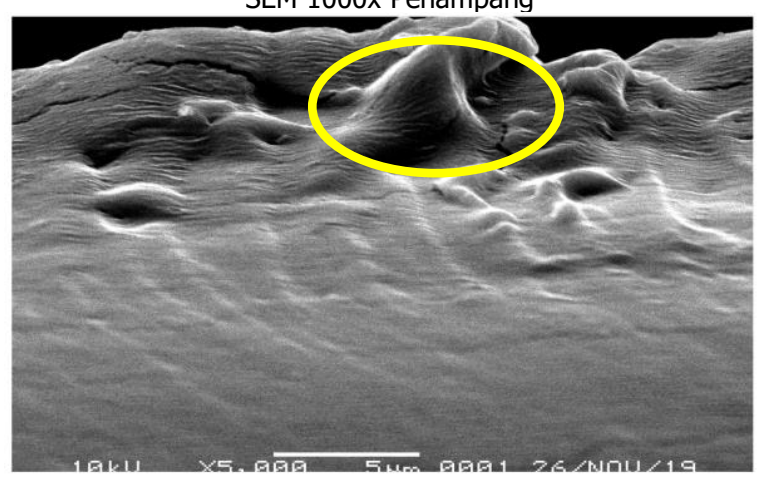

SEM 5000x Penampang

2 (c)

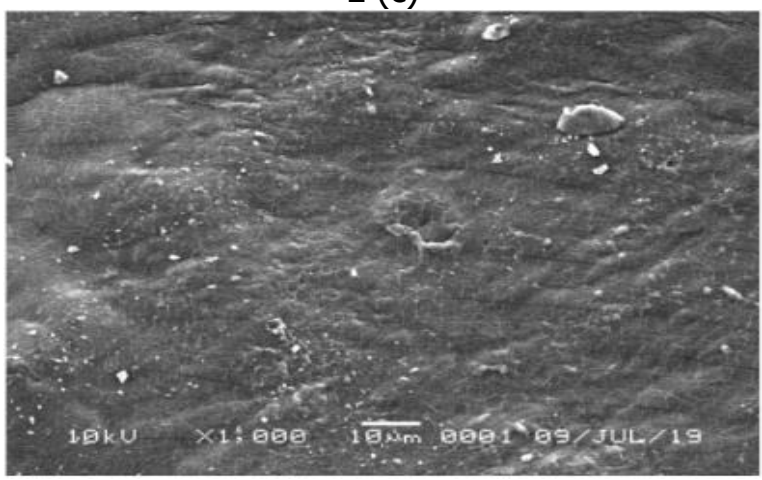

SEM 1000x permukaan
2 (b)

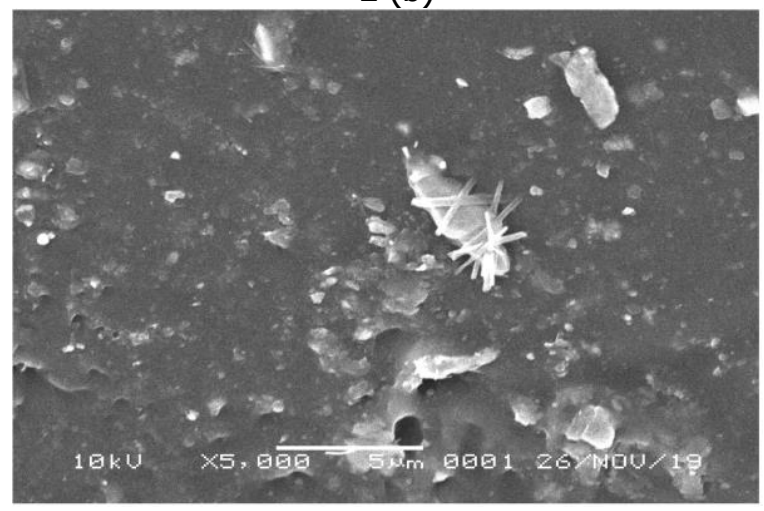

SEM 5000x permukaan

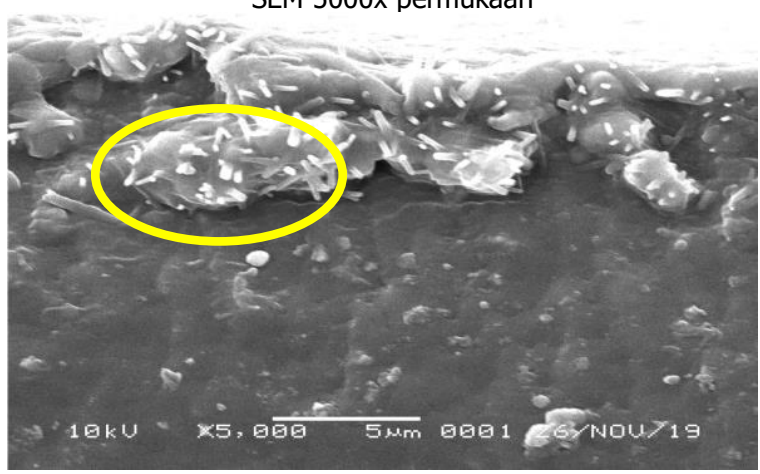

SEM 5000x penampang

2 (d)

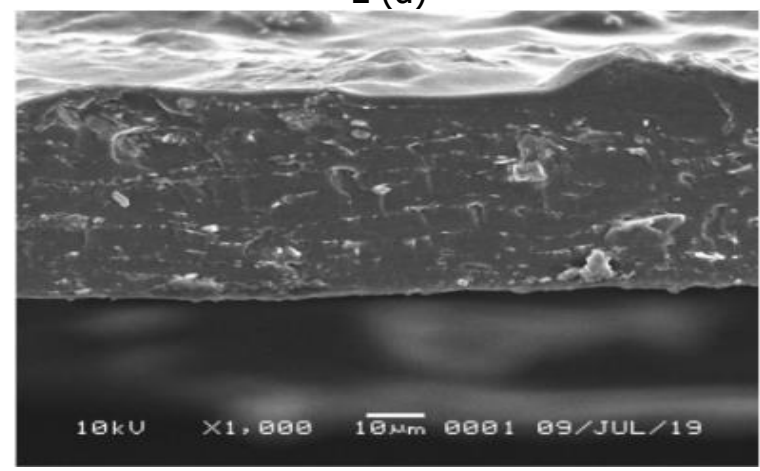

SEM 1000x penampang

194 Hamlan Ihsan, Desi Mustika Amaliyah, Dwi Harsono, Sri Hidayati, 


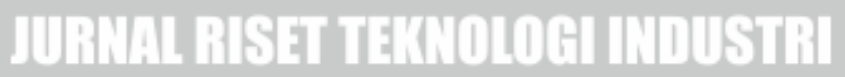

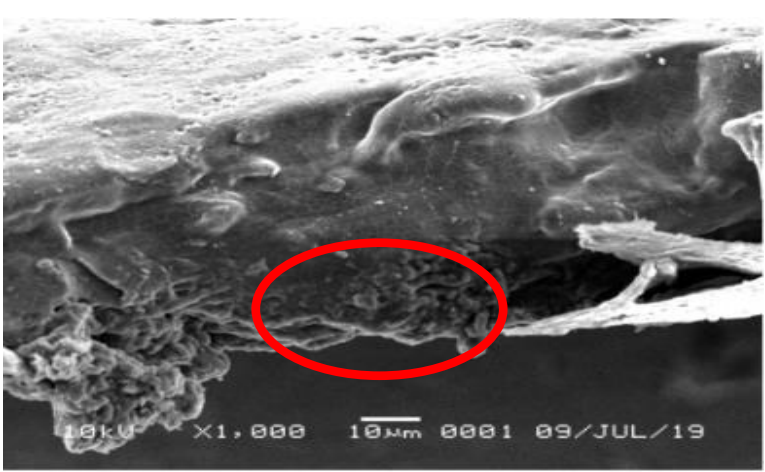

SEM 1000x penampang

2 (e)

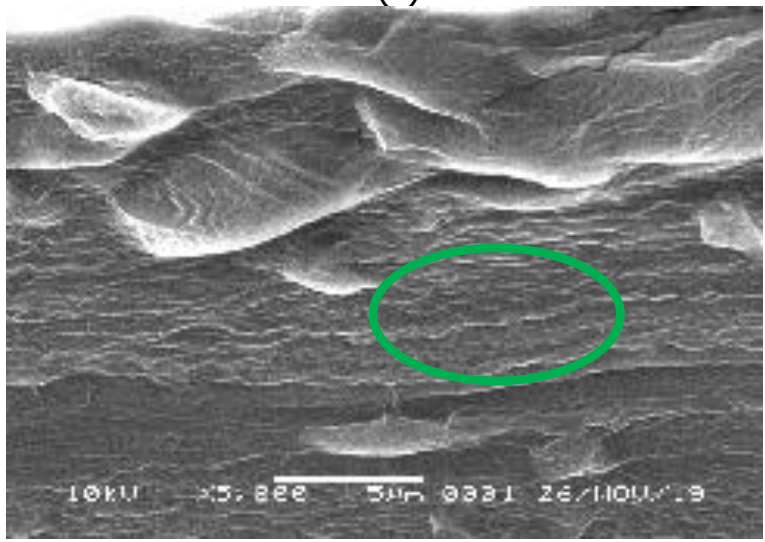

SEM 5000x penampang

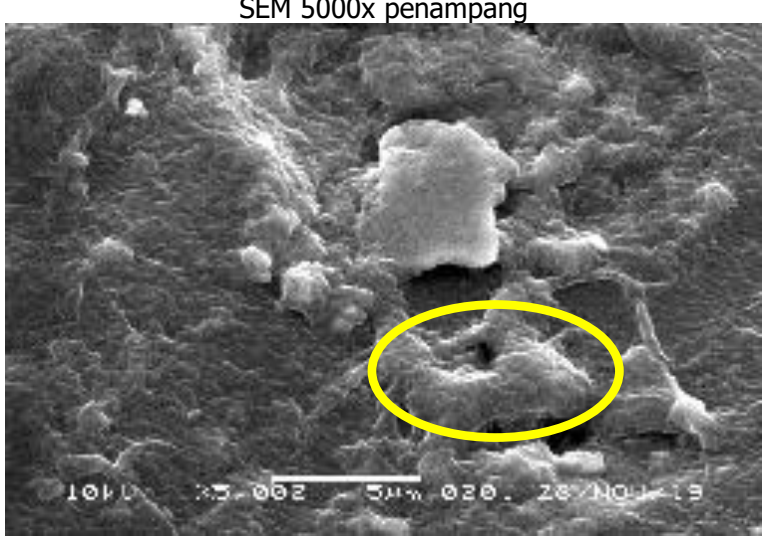

SEM 5000x permukaan

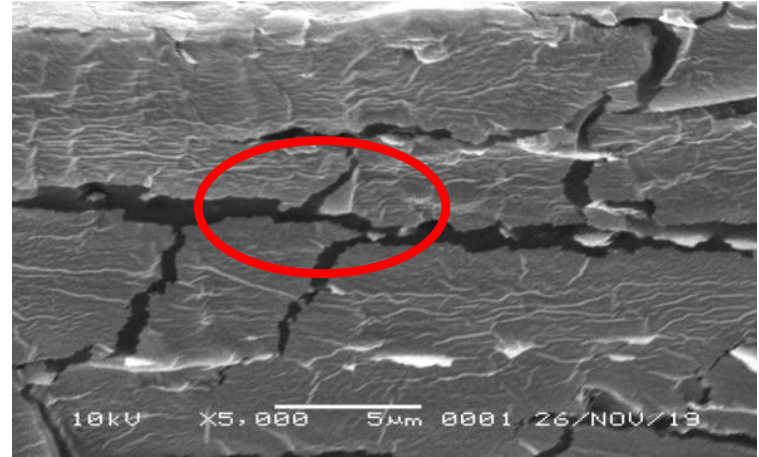

SEM 5000x penampang

$2(f)$

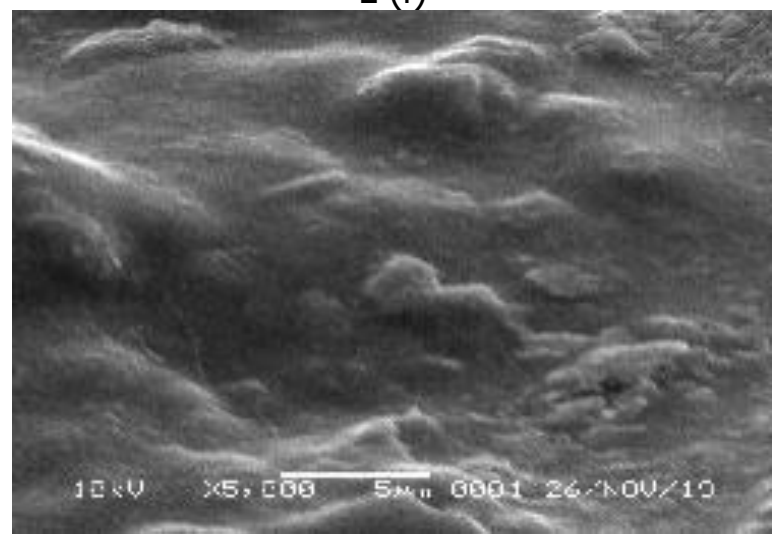

SEM 5000x penampang

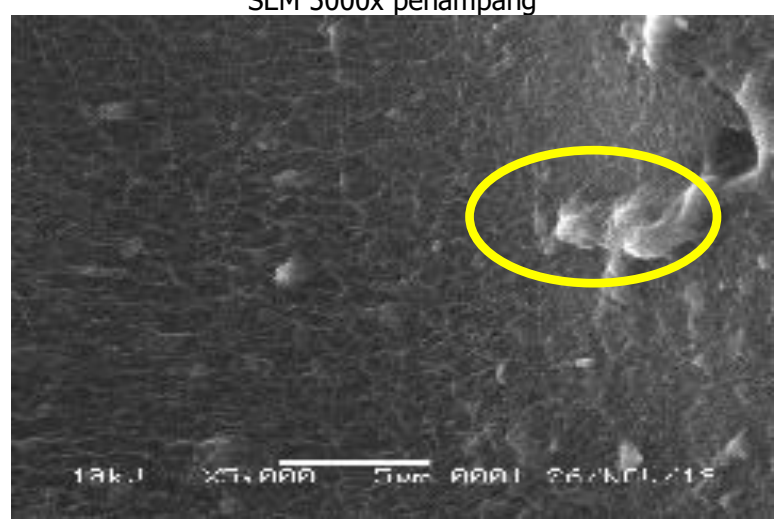

SEM 5000x permukaan

Gambar 4. Grafik hasil pengujian SEM (a) gelatin komersial, (b) cangkang kapsul komersial, (c) sagu + karagenan, (d) sagu + kaolin, (e) sagu modifikasi + karagenan, (f) sagu modifikasi + kaolin

Hasil SEM pada Gambar 2c dan 2d memiliki morfologi permukaan yang sangat kasar dan bahkan pecah - pecah. Pada perbesaran 5000x terlihat ada retakan yang diduga pengaruh dari serat yang membuat kaku dan mudah retak. Kurangnya gliserol dapat mempengaruhi keretakan dimana gliserol sebagai plasticizer dapat mengikat komponen dan meningkatkan elastisitas. Keretakan juga dapat meningkatkan air yang terserap lebih banyak (Setiani et al., 2013).

Pengujian SEM memperlihatkan bahwa tekstur pati sagu termodifikasi dengan penambahan filler karagenan pada Gambar 2e mengandung banyak zona putus-putus (discontinuous zone) sesuai dengan yang dikemukakan oleh Herliany et al. (2013) bahwa ini mengindikasikan bahwa keadaan biofilm tersebut kurang kompak dan padat sehingga 
menghasilkan kuat tarik yang rendah. Dilakukannya modifikasi dan variasi filler terbukti mampu meperbaiki struktur internal ditandai dengan berkurangnya zona putus-putus sehingga struktur lebih kompak dan padat.

\section{Pengujian keamanan bahan baku}

Hasil analisis kandungan Aflatoksin yang dilakukan di Seameo Biotrop Services Laboratory memberikan nilai pengujian yang dapat dilihat pada Tabel 1. Cemaran kontaminasi aflatoksin lebih sering terjadi pada daerah beriklim tropis karena suhu dan kelembabannya mendukung untuk pertumbuhan jamur. Aflatoksin memerlukan pH $5.5-7.0, \mathrm{RH} 85 \%$, kadar air yang tinggi, dan proses pembentukan ini dipengaruhi oleh faktor genetik Aspergillus flavus dan lamanya kontak dengan substrat (Kusuma, Kusnadi dan Winarsih, 2017). Pengujian aflatoksin sebagai syarat untuk bidang farmasi/ pangan dengan tujuan untuk menjamin tidak adanya kandungan beracun dalam bahan baku. Gambar 3. merupakan struktur kimia dari Aspergillus flavus yang memproduksi aflatoksin $\mathrm{B}$, dan $A$. parasiticus yang menghasilkan aflatoksin G.
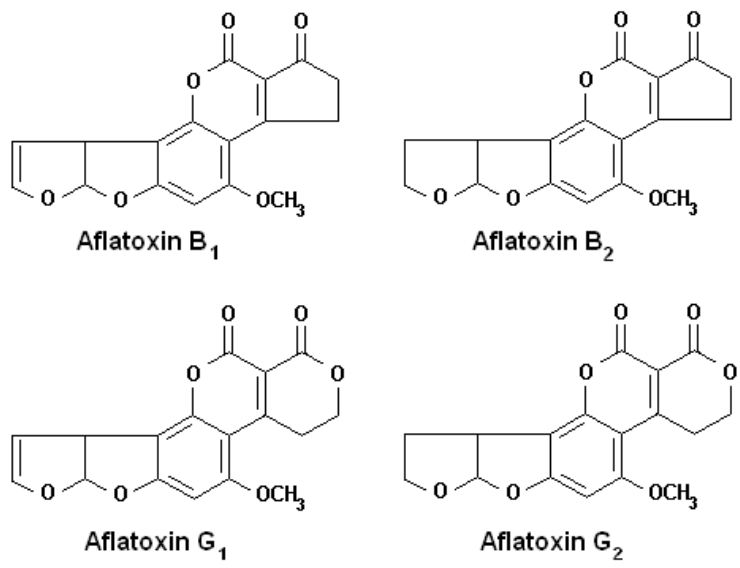

Gambar 5. Struktur kimia aflatoksin (Aini, 2012)

Berdasarkan data hasil penelitian pada Tabel 1. menunjukkan kadar aflatoksin di bawah standar sehingga aman untuk digunakan. International Agency for Research on Cancer (IARC) menerangkan aflatoksin termasuk dalam senyawa Kelompok 1, yakni senyawa yang bersifat karsinogenik pada manusia, terutama Aflatoksin B1 merupakan aflatoksin yang paling toksik (Aini, 2012). Selain bersifat karsinogenik, aflatoksin juga bersifat genotoksik, hepatoksik pada manusia, serta nefrotoksik dan imunosupresif pada hewan. Batas cemaran aflatoksin dalam makanan adalah sebesar 20 ppb (SNI 2009) dan dengan syarat aflatoksin B1 $\leq 5 \mathrm{ppb}$ (BBPOM, 2018).

Tabel 1. Pengujian Kandungan Aflatoksin

\begin{tabular}{|c|c|c|c|c|c|c|c|}
\hline \multirow{2}{*}{ Kode Contoh } & \multicolumn{4}{|c|}{ Kandungan Aflatoksin (ppb) } & \multirow{2}{*}{$\begin{array}{l}\text { Metode } \\
\text { Uji/ Alat }\end{array}$} & \multirow{2}{*}{$\begin{array}{c}\text { BBPOM } \\
\left(B_{1}\right)\end{array}$} & \multirow{2}{*}{$\begin{array}{c}\text { SNI } \\
\text { 7385:2009 } \\
\text { (Pangan) }\end{array}$} \\
\hline & $\mathrm{B}_{1}$ & $\mathrm{~B}_{2}$ & $\mathrm{G}_{1}$ & $\mathrm{G}_{2}$ & & & \\
\hline Sagu M + kaolin & $<1,42$ & $<6,72$ & $<5,09$ & $<0,66$ & KLT & $\leq 5 \mathrm{ppb}$ & $<20 \mathrm{ppb}$ \\
\hline Sagu $\mathrm{M}+$ karagenan & $<1,42$ & $<6,72$ & $<5,09$ & $<0,66$ & KLT & $\leq$ & $<20 \mathrm{ppb}$ \\
\hline Sagu + Karagenan & $<1,42$ & $<6,72$ & $<5,09$ & $<0,66$ & KLT & $\leq 5 \mathrm{ppb}$ & $<20 \mathrm{ppb}$ \\
\hline Sagu + kaolin & $<1,42$ & $<6,72$ & $<5,09$ & $<0,66$ & $\mathrm{KLT}$ & $\leq 5 \mathrm{ppb}$ & $<20 \mathrm{ppb}$ \\
\hline
\end{tabular}


Nama-nama istilah pada aflatoksin diberikan berdasarkan dari warna fluoresensi yang ditimbulkan pada medium agar dilihat di bawah sinar ultraviolet, seperti biru (blue atau B), atau hijau (green atau G). Aflatoksin B2 dan G2 merupakan analog dari derivat dihidro dari B1 dan G1. Di antara keempat isomer yang ditemukan, aflatoksin B1 (AFB1) merupakan yang paling toksik dan paling karsinogenik. Aflatoksin B2 bersifat karsinogenik ringan, kemungkinan karena enzim ini sebagian kecil diubah jadi AFB1 (Lewis et al., 2005).

Pada penelitian yang dilakukan Ramandani et al. (2020) tentang pengujian aflatoksin dimana hal ini dapat memberikan efek yang negatif khususnya pada manusia apabila secara tidak sengaja sumber makanan ataupun obat-obatan yang diambil dari bahan alam dikontaminasi aflatoksin. Ramandani et al. (2020) juga didalam penelitiannya menyebutkan bahwa sumber kaolin yang mengandung bentonite mampu menetralisir apabila terdapat kandungan aflatoksin.

\section{KESIMPULAN}

Pati sagu memiliki potensi untuk dijadikan pengganti gelatin komersial hasil pengujian sifat morfologi. Hasil analisis berdasarkan gugus fungsi dengan menggunakan FTIR terdapat kesamaan nilai bilangan gelombang gelatin dengan sagu modifikasi dengan filler karagenan dan kaolin yaitu masing-masing adalah $3272 \mathrm{~cm}^{-1}$ dan $3283 \mathrm{~cm}^{-1}$. Sedangkan pada pengujian berdasarkan tekstur dengan menggunakan SEM baik pembesaran 1000 ataupun 5000 kali pada sagu modifikasi dengan filler kaolin yang memiliki lebih sedikit zona putus-putus (discontinuous zone) serta tampilan pada permukaan yang lebih padat dan rata dari pada variasi yang lain. Tingkat keamanan dari sediaan berdasarkan pengujian kandungan aflatoksin memenuhi standar pangan yaitu $<20 \mathrm{ppb}$ dan BPOM yaitu $\leq 5 \mathrm{ppb}$ untuk jenis aflatoksin $\mathrm{B}_{1}$.

\section{UCAPAN TERIMA KASIH}

Ucapan terimakasih disampaikan kepada Badan Penelitian dan Pengembangan Industri Kementerian Perindustrian RI yang telah memberikan pendanaan TA. 2019 sehingga penelitian ini dapat diselesaikan. Kemudian ucapan terimakasih juga disampaikan kepada para Peneliti, Perekayasa, dan analis Baristand Industri Banjarbaru yang membantu penelitian ini dengan baik.

\section{DAFTAR PUSTAKA}

[AOAC] Association of official analytical chemist. 2005. Natural toxins. Di dalam: Horwitz W, editor. Official Methods of Analysis of AOAC International. Ed ke-18. Gaithersburg (US): AOAC. hlm 11.

Aini, N. 2012. Aflatoksin: Cemaran dan Metode Analisisnya dalam Makanan. Jurnal Kefarmasian Indonesia, 2(2), 54-61.

Badan Pusat Statistik. 2014. Data Impor Gelatin. Maret. BPS. Indonesia

Bantacut, T. 2011. Sagu: Sumberdaya untuk Penganekaragaman Pangan Pokok. Jurnal Pangan 20(1): 27-40.

Balai Besar Pengawas Obat dan Makanan. 2018. Persyaratan Mutu Obat. Jakarta.

Crankovic, G. M. 1986. Hand Book. in Material Characterization. Vol 10. Amerika: ASM.

Fakharian, M. H., N. Tamimi., H. Abbaspour., A. M. Nafchi., dan A.A. Karim. 2015. Effects of k-Carrageenan on Rheological Properties of Dually Modified Sago Starch: Towards Finding Gelatin Alternative for Hard Capsules. Carbohydrate Polymers 132: 156-163.

Fessenden, R. J. and Fessenden, J. S. 1982. Kimia Organik. 3rd edn. Edited by P. . Aloysius Hadyana Pudjaatmaka. Erlangga.

Herliany, N. E., Santoso, J. dan Salamah, E. 2013. Karakteristik Biofilm Berbahan Dasar Karagenan. Jurnal Akuatika IV(1): 10-20.

Ihsan, H., I. D. G. P. Prabawa., D. Harsono., R. Nintasari.,R. Apriani., dan A. B. Nurcahyo. 
2019. Pengujian Sifat Fisik dan Cemaran Mikroba pada Cangkang Kapsul Pati Sagu Rumbia (Metroxylon sagu Rottb) dan Karagenan. Jurnal Riset Industri Hasil Hutan 11(1): 13-22.

Ihsan, H., Khairiah, N. dan Rufida. 2018. Karakteristik Sifat Fisik dan Kimia Edible Film Pati Sagu Rumbia (Metroxylon sagu Rottb) untuk Bahan Baku Cangkang Kapsul. Jurnal Riset Industri Hasil Hutan 10(2): 55-62.

International Agency for Research on Cancer. Aflatoxin. IARC Monographs 2002; 82: 171.

Kusuma, T. S., Kusnadi, J. dan Winarsih, S. 2017. Kombinasi Pasteurisasi, Suhu, dan Masa Simpan Terhadap Kadar Aflatoksin pada Selai Kacang Tanah. Indonesian Journal of Human Nutrition 4(2): 88-96.

Kristianto, W. 2014. Komposit Alginat Karaginan dari Alga Merah (Eucheuma spinosom) sebagai Material Drug Delivery. Universitas Airlangga.

Lewis L., Onsongo M., Njapau H., Rogers HS., Luber G., Kieszak S., Nyamongo J., Backer L., Dahiye AM., Misore A., DeCock K. 2005. Aflatoxin contamination of commercial maize products during an outbreak of acute aflatoxicosis in Eastern and Central Kenya. Environ Health Perspect 113 (12): 1763-1767.

Maulani, R. R., F. Dedi., F. Kusnandar., dan T. C. Sunarti. 2013. Sifat Fungsional Pati Garut Hasil Modifikasi Hidroksipropilasi dan Taut Silang. Jurnal Teknologi dan Industri Pangan 24(3): 60-67.

Oladzadabbasabadi, N., S. Ebadi., A. M. Nafchi., A.A. Karim., dan S. R. Kiahosseini. 2016. Functional Properties of Dually Modified Sago Starch/k-Carrageenan Films: an Alternative to Gelatin in Pharmaceutical Capsules. Carbohydrate Polymers 160: 43-51.

Rakhman, F. A. dan Darni, Y. 2017. Aplikasi Edible Film dari Rumput Laut Eucheumma cottoni dan Pati Sorgum dengan Plastisizer Gliserol dan Filler $\mathrm{CaCO}_{3}$ Sebagai Bahan Pembuat Cangkang Kapsul. Jurnal Kelitbangan 5(2): 172-183.

Ramandani, D., R. Ummam., N. Hidayah., N. Wanda., Y. Dalimunthe., S. Indarjulianto., dan A. Nurrorozi. 2020. Potensi Bentonite Clay dan Karbon Aktif sebagai Aflatoksin Binders Berdasarkan Gambaran Imunologis dan Histopatologis pada Ayam Buras. Jurnal IImu Peternakan dan Veteriner Tropis 10(1): 63-69.

Ratnasari, I., S. S. Yuwono., H. Nursyam., dan S. B. Widjanarko. 2013. Extraction and Characterization of Gelatin from Different Fresh Water Fishes as Alternative Sources of Gelatin. International Food Research Journal 20(6): 3085-3091

Roswiem, A. P. dan Kusuma, I. 2018. Identifikasi Gelatin dalam Obat Bentuk Sediaan Tablet menggunakan Metode Fourier Transform Infra Red (FTIR) Spectroscopy. Indonesian Journal of Halal 1(1): 58-72.

Said, M. I., S. Triatmojo., E. Yuny., dan F. Achmad. 2011. Karakteristik Gelatin Kulit Kambing yang Diproduksi melalui Proses Asam dan Basa. AGRITECH31(3): 1-9.

Sari, R. P., S. T. Wulandari., dan D. H. Wardhani. 2013. Pengaruh Penambahan Ekstrak Bawang Putih (Allium sativum) Terhadap Karakteristik Edible Film Pati Goyang (Canna edulis Kerr). Jurnal Teknologi Kimia dan Industri 2(3): 82-87.

Setiani, W., Sudiarti, T. dan Rahmidar, L. 2013. Preparasi Dan Karakterisasi Edible Film Dari Poliblend Pati. Valensi 3(2): 100-109.

Setijawati, D. 2017. Penggunaan Eucheuma SP dan Chitosan sebagai Bahan Edible Film terhadap Kualitasnya. Journal of Fisheris and Marine Sciences and Marine Science 1(1): 6-14.

[SNI] Standar Nasional Indonesia. 7385:2009. 2009. Batas Maksimum Kandungan Mikotoksin dalam Pangan. Jakarta (ID): Badan Standardisasi Nasional.

Syafiqoh, F. 2014. Analisis Gelatin Sapi dan Gelatin Babi pada Produk Cangkang Kapsul Keras Obat dan Vitamin Menggunkan FTIR dan KCKT. Skripsi. Prosgram S1 Farmasi UIN Syarif Hidayatullah. Jakarta. 
Wahida dan Limbongan, A. A. 2015. Pemanfaatan Ampas Sagu Sebagai Bahan Dasar Kompos Pada Beberapa Dosis Pencampuran Dengan Kotoran Sapi. Agricola 5(1): 1-8.

Widyaningsih, S., Kartika, D. dan Nurhayati, Y. T. 2012. Pengaruh Penambahan Sorbitol dan Kalsium Karbonat Terhadap Karakteristik dan Sifat Biodegradasi Film dari Pati Kulit Pisang. Molekul. 7(1): 69-81.

Yuliasih, I., T. T. Irawan., I. Sailah., H. Pranamuda., K. Setyowati., dan T. C. Sunarti. 2007. Aplikasi Pati Sagu dan Modifikasinya sebagai Komponen Plastik. Seminar Tjipto Utomo bandung. 30 Agustus: D5-1 - D5-9. 